\title{
The Role of Technical and Vocational Training for Entrepreneurship Development and Business Skills in the Boushehr Province Technical and Vocational Training IRAN Aspect.
}

\author{
Mohamad Behroozi \\ Department of Management, Bushehr Branch, Islamic Azad University, Bushehr, Iran \\ dr_m_behroozi@yahoo.com
}

\begin{abstract}
This study was to identify the role of technical and vocational training in entrepreneurship development and business skills in the main office of B. province technical and vocational training. The corelational study was conducted. The population consisted of 1500 apprentices among which 420 persons were randomly selected according to Cochran formula based on a systematic sampling method. Data is gathered via a researcher-structured questionnaire containing 35 items based on Likert scale. Content validity and Cronbach'S Alpha $(\alpha=/ 94)$ are used. The data was analysed using SPSS software. The descriptive and inferential statistics are also used to examined the hypotheses. The result showed that there was a significant relationship between technical and vocational training and dimensions of entrepreneurship in the apprentices that includes: technical and vocational training, knowledge and technical ability, success seeking.
\end{abstract}

Key Words: entrepreneurship, creativity, business skills, technical and vocational training

\section{INTRODUCTION}

Entrepreneurship is known as a key factor in the economic development of the modern age, and at the center of international competition it is entrepreneurial firm sth at their competitive sharp edge focused on organizational flexibility and continuous change in strategy, processes, products and plans (Khajeian, 2015). Rapid changes in science and technology in recent years have faced countries such as the least developed countries with new challenges and problems. Amongs other, the role of entrepreneurship and entrepreneurs can be decisive and maybe that's why interpreted entrepreneurship as the engine of economic growth. Through the discovery of opportunities and utilization of it, create employment opportunities, changes in the living environment and entrepreneurship can help to develop the country (Pour Dariani Ahmed, 2016). Policy makers believe that our country to achieve its development goals should be involved actively in the global economy. Initiates actions such removal of non-tariff barriers, tax reform, economic liberalization, similar exchange rate and the same support and encouragement of foreign investment is one of the activities that have been planned and implemented. But one of the key issues that must be addressed in this advantage of efficient and professional entrepreneurs, because with the gradual competition business environment and given the competitors, that are very smart and powerful, work is not easy. Changes in the business environment of the country and the world require the use of professionals and entrepreneurs 
(Bozorgrah, 2010).Technical and professional education in today's economy and culture of Iran, in particular the acceleration of the process is crucial; because the underlying investments and enhanced tools and generally physical capital without human capital unused or it is (Gerami Nejad, 2011). Considering that one of the causes of unemployment in the country is lack of required skills of the labour market by job seekers, it is expected that Iran Technical \& Vocational Training Organization by providing training skills can play a significant role in the development of entrepreneurship and business skills.

Study the system of technical and vocational training in some countries indicates that this education system has an important role in entrepreneurship graduates and the economic and social development of communities.

\section{Literature Review}

Tomecko (1982) in a study in 192 in technical and vocational centres of Baylor on entrepreneurs found that the emphasis should be on the financial lessons. And the second course that more emphasis should have been fixed on it was entrepreneurial management. Baylor University study in 1982 on Entrepreneurship students showed that more emphasis should be on financial education. And in their opinion the second course that more emphasis been fixed on it was entrepreneurial management.

Gates (1992) admits the four most important factors for the emergence of entrepreneurship: Economic factors market benefits, the availability of capital. Non-economic factors the acceptance of CE (culturally), social mobility, security, and factors such as social class, power and control. Psychological factors such as the need for achievement, motivation and risk taking. The combination of production factors in order to make change in products and services.

Another study is identified environmental impacts as a particular and strong need to start a new business. For example, due to the dismissal of the previous work one has. Another environmental impact is the models of role, both in the micro (parents as entrepreneurs) and macro social contexts (Hindle, 2002). McPherson (2009) suggested that to identify the determinants of entrepreneurship and the creation of new business were identified the following factors: To finance, supportive government regulations, market opportunities, access to support services, the supply of skilled workers and supportive government regulations.

Morris (2008) suggested that the economic and political factors affecting the formation of small businesses have identified three factors stimulating entrepreneurship: Entrepreneurial motivation, skills and resources required. Samad Aqaii (2010) concluded that technical and vocational training has considerable success in developing a skilled workforce(human capital) and training human resources self-employed(entrepreneurs) and can be used as a way to develop the human capital of the role.

Moosavi Bazargani (2013) explores issues of entrepreneurship education. He concluded that advanced countries in the process of socio - economic development that seriously paid attention to entrepreneurship education and training for entrepreneurs is among their development 
programs. Studies show that training entrepreneurship programs has been accomplished in various countries with government policy and administrative support. These policy and support included: improve the culture and promote the entrepreneurial spirit, structural reforms and institution-building, creating a public- private educational institution, helping to set up and run an orphanage in a small business, entrepreneurship education through schools, universities and government agencies, entrepreneurship education through distance learning, media, financial advice-technical and management and to inform the public.

Saidi Kia (2015) conducted a study to investigate the relationship between organizational climate of public school with entrepreneurial spirit of secondary female pupils. The results showed that 1) There is a significant relationship between organizational climate and entrepreneurial spirit of students, 2) The indicator $\mathrm{s}$ of entrepreneurial spirit(achievement motivation, self-esteem, creativity, internal locus of control, foresight, and risk appetite) in students is higher than average, 3) There is a significant relationship between organizational climate and the indicators of entrepreneurial spirit.

Samad Aqaii (2010), in a study entitled "investigating the relationship between entrepreneurial characteristics of managers and their effectiveness in female high schools in Kerman on statistics groups" investigated 57managers and concluded that there is not a significant relationship between personality, history and background, and experience traits of entrepreneurship Kerman female high school.

\section{Research questions}

A) The main hypothesis:

There is a relationship between technical and vocational training and the development of entrepreneurship and business skills.

B) The secondary research hypotheses:

1. There is a relationship between technical and vocational training and the development of innovation and creativity of students.

2. There is a relationship between technical and vocational training and the trainees' acquisition of knowledge and technical power.

3. There is a relationship between technical and vocational training and confident of the students.

4. There is a relationship between technical and vocational training and risk taking of the students.

5. There is a relationship between technical and vocational training and Willingness to take responsibility in students.

6. There is a relationship between technical and vocational training and achievement of the students. 


\section{Method}

This is a descriptive-surveying study and the statistical population consisted of 1500 apprentices among which 420 persons are randomly selected according to Cochran formula based on a systematic sampling method. Data is gathered via a researcher- structured questionnaire containing 35 items based on Likert scale. Content validity and Cronbach's Alpha $(\alpha=\% 94)$ are used. Using SPSS software that data is analysed while descriptive and inferential statistics are also used such as Frequency, Mean, SD, Spearman's correlation coefficient and Regression.

\section{Result}

The first hypothesis is there is a relationship between technical and vocational education and creating innovation and creativity of students.

Table 1

The correlation between innovation and creativity and technical and vocational education

\begin{tabular}{llll}
\hline $\begin{array}{l}\text { Sample } \\
\text { Correlated variable }\end{array}$ & Average & Standard deviation & correlation coefficient \\
\hline $\begin{array}{l}\text { Creativity and } \\
\text { Innovation }\end{array}$ & 22.07 & 4.606 & $0.87 * *$ \\
\hline
\end{tabular}

As is clear from Table 1, correlation between technical and vocational education and creativity and innovation in the sample is equal to 0.87 , which is significant in $p<0.01$. So the first hypothesis is confirmed.

The second hypothesis: There is a relationship between technical and vocational education and acquisition knowledge and technical ability of trainees.

Table 2

The correlation between acquisition knowledge and technical ability and technical and vocational education 


\begin{tabular}{llll}
\hline $\begin{array}{l}\text { Sample } \\
\text { Correlated variable }\end{array}$ & Average & Standard deviation & correlation coefficient \\
\hline $\begin{array}{l}\text { Acquisition } \\
\begin{array}{l}\text { knowledge } \\
\text { technical ability }\end{array}\end{array}$ & 14.24 & 3.20 & $0.83^{* *}$ \\
\hline
\end{tabular}

As shown in Table 2 the correlation between acquisition knowledge and technical ability and technical and vocational education is 0.83 , which is significant in $p<0.01$. This means that the null hypothesis is rejected and the researcher hypothesis is accepted.The third hypothesis: There is a relationship between technical and vocational education and self confidence of students.

Table 3

The correlation between technical and vocational education and self confidence

\begin{tabular}{llll}
\hline $\begin{array}{l}\text { Sample } \\
\text { Correlated variable }\end{array}$ & Average & Standard deviation & correlation coefficient \\
\hline Self confidence & 18.74 & 4.3 & $0.76^{* *}$ \\
\hline
\end{tabular}

As shown in Table5-3, the mean and standard deviation ofthedependentvariableis74/18and3/4 respectively, and the correlation between self confidence of students and technical and vocational education is 0.76 which is significant in $p<0.01$. So the researcher hypothesis is accepted.The fourth hypothesis: There is a relationship between technical and vocational education and risk taking of students.

Table 4

The correlation between technical and vocational education and risk taking

\begin{tabular}{llll}
\hline $\begin{array}{l}\text { Sample } \\
\text { Correlated variable }\end{array}$ & Average & Standard deviation & correlation coefficient \\
\hline Risk taking & 17.9 & 4.038 & $0.85^{* *}$ \\
\hline
\end{tabular}

As shown in Table 4, the mean and standard deviation of risk-taking variable on apprentices are respectively 9.17 and 038/5, and the correlation coefficient between risk-taking variable on apprentices and technical and vocational education is 0.85 which is significant in $p<0.01$. This means that the null hypothesis is rejected and the researcher hypothesis is accepted.The fifth hypothesis: There is a relationship between technical and vocational education and willingness to take responsibility in students.

Table 5

The correlation between technical and vocational education And willingness to take responsibility 


\begin{tabular}{llll}
\hline $\begin{array}{l}\text { Sample } \\
\text { Correlated variable }\end{array}$ & Average & Standard deviation & correlation coefficient \\
\hline $\begin{array}{l}\text { willingness to take } \\
\text { responsibility }\end{array}$ & 17.72 & 3.8 & $0.86^{* *}$ \\
\hline
\end{tabular}

As shown in Table 5, the mean and standard deviation of willingness to take responsibility is respectively 17.72 and 3.8 , and the correlation coefficient between willingness to take responsibility in students and technical and vocational education is 0.86 which is significant in $\mathrm{p}<0.01$. So, the null hypothesis is rejected and the researcher hypothesis is accepted.The sixth hypothesis: There is a relationship between technical and vocational education and students' achievement.

Table 6

The correlation between technical and vocational education And students' achievement

\begin{tabular}{llll}
\hline $\begin{array}{l}\text { Sample } \\
\text { Correlated variable }\end{array}$ & Average & Standard deviation & correlation coefficient \\
\hline $\begin{array}{l}\text { students' } \\
\text { achievement }\end{array}$ & 18.34 & 3.92 & $0.86^{* *}$ \\
\hline
\end{tabular}

As shown in Table 6, the mean and standard deviation of students' achievement is respectively 18.34 and 3.92, and the correlation coefficient between students' achievement and technical and vocational education is 0.86 which is significant in $p<0.01$. So the researcher hypothesis is accepted. The main hypothesis - There is a relationship between technical and vocationaleducationandentrepreneurshipdevelopmentandbusinessskills.

Table 7

The Correlation between Technical and Vocational Education and Entrepreneurship Development and Business Skills

\begin{tabular}{llll}
\hline $\begin{array}{l}\text { Sample } \\
\text { Business skills }\end{array}$ & Average & Standard deviation & correlation coefficient \\
\hline Business skills & 18.07 & 3.7 & $0.83^{* *}$ \\
\hline
\end{tabular}

As can be seen in the table above, the mean and standard deviation of business skills is respectively 18.07 and 3.7, and the correlation coefficient between business skills and entrepreneurship with technical and vocational educationis 0.83 which is significant in $\mathrm{p}<$ 0.01. Therefore the main hypothesis is also confirmed. Evaluate the correlation between variables 
found that there is a significant relationship between technical and vocational education and entrepreneurship development and business skills.

Table 8

Multiple Correlation of Technical And Vocational Education and Entrepreneurship Development and Business Skills Using Step Method

\begin{tabular}{|c|c|c|c|c|c|}
\hline $\begin{array}{l}\text { Criterion } \\
\text { variable }\end{array}$ & $\begin{array}{l}\text { Predictor } \\
\text { variable }\end{array}$ & $\begin{array}{l}\text { Multi variable } \\
\text { correlation } \\
\text { coefficient } \\
\text { (mr) }\end{array}$ & $\begin{array}{l}\text { The } \\
\text { coefficient of } \\
\text { determination } \\
\text { (RS) }\end{array}$ & $\begin{array}{l}\mathrm{F} \text { ratio and } \\
\text { its } \\
\text { probability }\end{array}$ & $\begin{array}{l}\text { Regression } \\
\text { coefficient } \\
\text { of B }\end{array}$ \\
\hline \multirow{3}{*}{$\begin{array}{l}\text { Technical } \\
\text { and } \\
\text { vocational } \\
\text { education }\end{array}$} & creativity & 0.87 & 0.76 & $\begin{array}{l}50.38 \\
P<0.001\end{array}$ & $\begin{array}{l}\mathrm{B}=0.87 \\
\mathrm{~T}=10.71 \\
\mathrm{P}<0.001\end{array}$ \\
\hline & $\begin{array}{l}\text { Creativity } \\
\text { Take } \\
\text { responsibility }\end{array}$ & 0.94 & 0.89 & $\begin{array}{l}27.26 \\
P<0.001\end{array}$ & $\begin{array}{l}\mathrm{B}=0.53 \\
\mathrm{~T}=22.155 \\
\mathrm{P}<0.001\end{array}$ \\
\hline & $\begin{array}{l}\text { Creativity } \\
\text { Take } \\
\text { responsibility } \\
\text { Self- } \\
\text { confidence }\end{array}$ & 0.96 & 0.93 & $\begin{array}{l}50.38 \\
P<0.001\end{array}$ & $\begin{array}{l}\mathrm{B}=0.27 \\
\mathrm{~T}=18.55 \\
\mathrm{P}<0.001\end{array}$ \\
\hline
\end{tabular}

As shown in Table 8, multi variable correlation coefficient for the linear combination of independent variables and technical and vocational education equals to 0.96 which is significant in $\mathrm{p}<0.001$. 


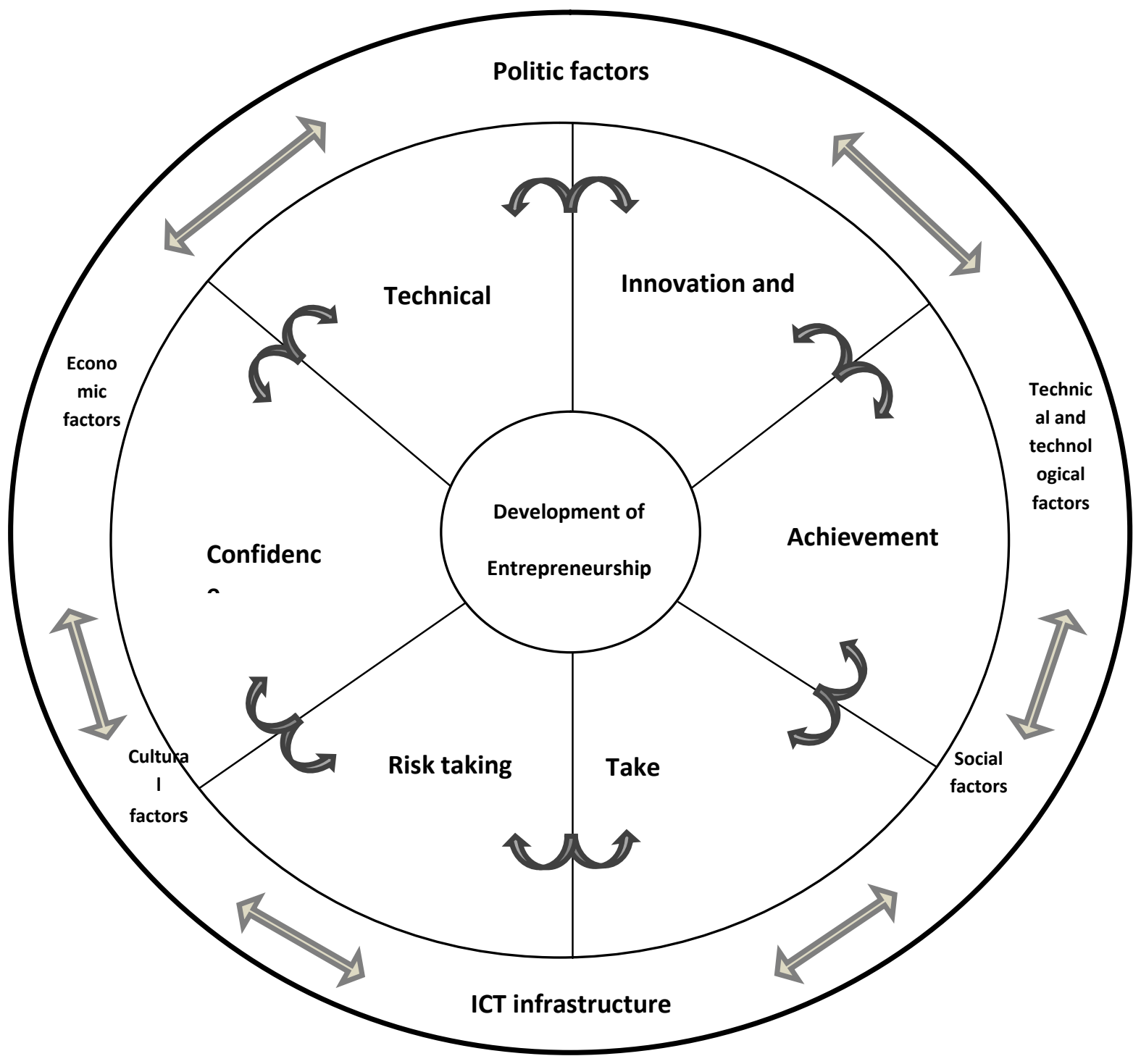

Figure 1. Conceptual Framework of Enterpreneurs

\section{Discussion}

It is essential to note that the obtained multi variable correlation coefficient is more than the simple correlation coefficients of each variable of technical and vocational education and 
entrepreneurship. The regression coefficients (B) show that among the predictors the creativity, taking responsibility, and self-confidence variables are the best predictors for technical and vocational education, entrepreneurship, and business skills. Moreover, the coefficient of determination of creativity increases with taking responsibility and self-confidence which is significant in $\mathrm{p}<0.01$. The present research confirm past study that suggest creativity, taking responsibility, and self confidence was predictors of entrepreneurship and business skills (Aqaii, 2010).

Creativity is a very important element in the business and entrepreneur world (Probst, Stewart, $\&$ Tierney, 2007). This is because the challenges facing the business world is very complex and demanding, also the changes happen very quickly. Only through creativity, all these challenges can be solved effectively. It becomes natural that creativity has a relationship with business skills and enterpreneurship. This study confirms the above, which shows a significant relationship between creativity with enterpreneurship and business skills.

Self-confidence becomes an important personality aspect for the individual in the face of the pressures and challenges of life. Self-confidence refers to the individual's belief that he is capable and has the capacity and competence to solve a problem. In the world of business and enterpreneurship, the belief that he is capable of facing the challenges that exist, becomes a power to succeed. Strong confidence will overcome doubts. In the business world, selfconfidence becomes an important aspect for the individual. This study shows that selfconfidence has a significant relationship with business skills and enterpreneurship.

Taking responsibility is a characteristic of a mature person. The ability to take responsibility becomes a part of the business world. The ability to take responsibility is needed when the individual faces an uncertain situation. In the business world, the individual is always faced with an uncertain situation, so the ability to take responsibility becomes the determinant of individual success. This study confirmed a significant relationship between the ability to take responsibility with business skills and entrepreneurship.

\section{Conclusion}

This study shows that creativity, taking responsibility and self confidence are significant predictors of business skills and entrepreneurship. For a recommendation, this study suggest that school needs to give a set of training to improve creativity, ability to take responsibility, and increase self confidence for their students. It is important to ensure students' success in developing their business skills and entrepreneurial spirit. Without creativity, taking responsibility and self confident, student cannnot develop their business skill and entrepreneurship in the future. 


\section{References}

Bozorgrah, A., (2010), The basic strategies for training entrepreneurs. Taavon monthly, No. 135.

Feizi, K., \& Moqadasi, M. (2011). Research In concepts, functions and entrepreneurship courses. Quarterly of Industrial, No.2

Gates, B. (1992). Business at the speed of thought. New York: Time Warner.

Gerami Nejad, A., (2011). Entrepreneur. Tehran: Ilar Publication and Distribution Center.

Hindle, K. (2002). A grounded theory for teaching entrepreneurship using simulation games. Simulation and Gaming, 33(2), 236-242.

Khajeian, D. (2015). Identification of entrepreneurial opportunities in the toy industry. Unpublished Thesis. School of Management, Tehran University

McPherson, G. (2003). Social Innovation Through Entrepreneurial Activity. Canadian Center For Social Entrepreneurship, CCSE Report.

Morris,Morris (2006). Entrepreneurial Intensity. In Michael Hitt \& Duane Ireland, Entrepreneurship, Victoria: Blackwell Publishing, pp. 91-95

Pour Dariani, A, M. (2016). Entrepreneurship, definitions, theories and models. Tehran: Pardis College Publishing Company.

Probst, T. M., Stewart, S. M., \& Tierney, B. W. (2007) Productivity, counterproductivity and creativity: The ups and downs of job insecurity. Journal of Occupational and Organizational Psychology, 80, 479-497.

Saidi Kia, M., (2015). Principles of entrepreneurship. Tehran: Kia Publication.

Samad Aqaii, J., (2010). Entrepreneurial organizations. Tehran: State Management Publication.

Samad Aqaii, J., (2012). Creativity is the essence of entrepreneurship, First edition, Tehran: Tehran University Centre for Entrepreneurship, University Press.

Tomecko, J. (1982). Entrepreneurship Training for Enterprise Growth. Laos: GTZ Publisher. 